\title{
The Concept of Inter-Racial Relationship from Al-Ta'arruf Perspective
}

\author{
Akila Mamat, Aminuddin Basir@Ahmad, Shamsuddin Yabi, Fadlan Mohd \\ Othman
}

To Link this Article: http://dx.doi.org/10.6007/IJARBSS/v10-i12/8211

DOI:10.6007/IJARBSS/v10-i12/8211

Received: 07 September 2020, Revised: 09 October 2020, Accepted: 11 November 2020

Published Online: 27 November 2020

In-Text Citation: (Mamat et al., 2020)

To Cite this Article:Mamat, A., Basir@Ahmad, A., Yabi, S., \& Othman, F. M. (2020). The Concept of Inter-Racial Relationship from Al-Ta'arruf Perspective. International Journal of Academic Research in Business and Social Sciences, 10(12), 15-25.

\section{Copyright: (c) 2020 The Author(s)}

Published by Human Resource Management Academic Research Society (www.hrmars.com)

This article is published under the Creative Commons Attribution (CC BY 4.0) license. Anyone may reproduce, distribute, translate and create derivative works of this article (for both commercial and non-commercial purposes), subject to full attribution to the original publication and authors. The full terms of this license may be seen at: http://creativecommons.org/licences/by/4.0/legalcode

\section{Vol. 10, No. 12, 2020, Pg. 15 - 25}

Full Terms \& Conditions of access and use can be found at http://hrmars.com/index.php/pages/detail/publication-ethics 


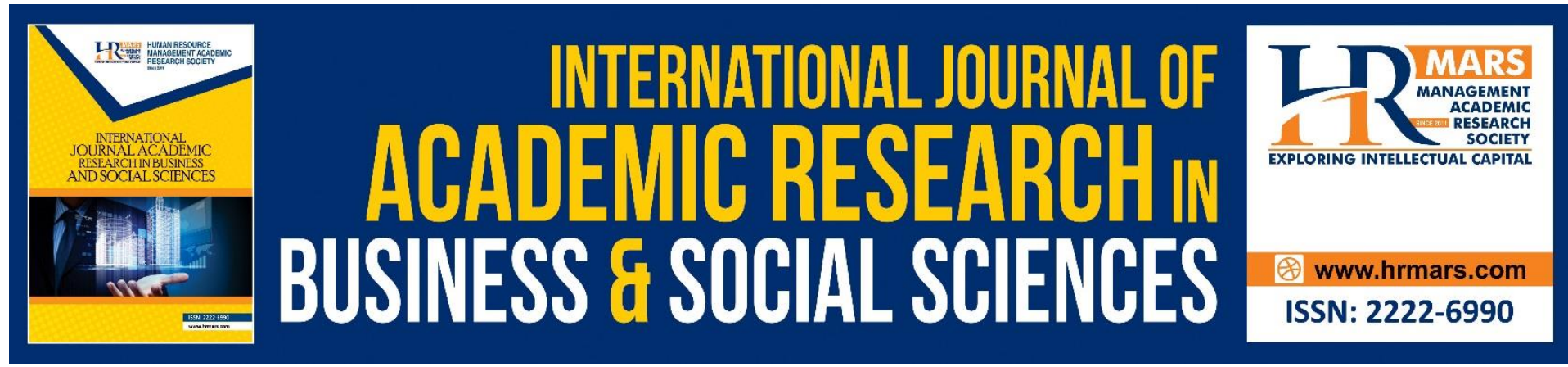

\title{
The Concept of Inter-Racial Relationship from Al- Ta'arruf Perspective
}

\section{1'Akila Mamat, ${ }^{2}$ Aminuddin Basir@Ahmad Phd, ${ }^{3}$ Shamsuddin Yabi Phd, ${ }^{2}$ Fadlan Mohd Othman Phd}

${ }^{1}$ Faculty of Islamic Contemporary Studies, Universiti Sultan Zainal Abidin (UniSZA), Terengganu, ${ }^{2}$ Center for General Studies, Universiti Kebangsaan Malaysia (UKM),

Bangi, Selangor, Malaysia, ${ }^{3}$ Faculty of Quran and Sunnah, Universiti Sains Malaysia (USIM), Nilai, Negeri Sembilan, Malaysia, ${ }^{2}$ Faculty Of Islamic Studies, Universiti Kebangsaan Malaysia (UKM), Bangi, Selangor, Malaysia

\begin{abstract}
The teaching of Islam as a whole suggests that community is a necessary part in building a united society. Through this good relationship, the country can be developed successfully and the people can enjoy the peace and prosperity. Therefore, it is very important to know the concept of relationship among the races, especially from the Islamic point of view. This article discusses the concept of relationship among the races from al-Taarruf's perspective. The objective of this article is to first review al-Ta'arruf' mening etymologically. Further discussion of al-Ta'arruf will also be seen based on explanations from the Quran, al-Sunnah and also explanations by Muslim scholars. On this topic the connection between takwa and al-Ta'arruf will also be scrutinize. The focus of the discussion will also touch on the wisdom of the existence of various tribes and nations. In order to achieve the objectives of this study, the qualitative method is used through the document analysis approach. The results show that al-Taakruf has a sense of diversification such as getting acquainted, interacting and managing various affairs. The study also shows that based on the Quran and al-Sunnah, Islamic teachings promote inter-racial relationship. The study also shows that the wisdom of multi-ethnicity is to appreciate the strength of each race. Finally, the study found that there is a strong relationship between religion and taarruf that leads to inter-racial cooperation.
\end{abstract}

Keywords: Concept, Inter-Racial Relationship, Al-Taarruf.

\section{Introduction}

Inter-racial relations are a very important process aimed at achieving unity to promote harmony within the country. An intimate inter-racial relationship cannot be achieved without a proper understanding of its purpose and the appreciation for its principles. A strong racial relations also contribute to socio-economic and political stability. In this case, inter-racial relations are through social interaction or in terms of Islamic civilization it is defined as alTa'arruf.

Al-Ta'arruf among the people is not just a human natural constitution to complement one another, it is also an order of Allah the Almighty who created people of many races, of 
different skin and culture. In the context of Islamic civilization, al-Ta'arruf is not only limited to recognizing a specific individual's name, but also has a wider and universal meaning. These include recognizing the culture of a nation, fostering cooperation, respecting differences and accepting them, respecting their rights and expressing their mutual trust.

\section{The Definition of Al-Ta'aruf}

$T a^{\prime}$ 'arruf' is the origin of a word that means to know. This sentence is from the point of view of Arabic language which means harmony and togetherness (Bu'ubayd 2013:49). It also means knowing two people who meet and get to know each other. In addition, it is understood that Takruf also means agreeing on certain matters whether in morals, customs, muamalat affairs and others. (Mas'ud, 1992; Mukhtar, 2008).

Furthermore, al-Taarruf's words means that they are related to one another based on a sense of calm and peace (Ibn-Faris, 1999: 282 ). Other meanings included in al-Taaruf are good deeds and practices, responsibility for giving nafkah, doing good deeds, good friendships with family members and others. (Ibn-Manzur, 1993: 239).

It also refers to the sense of governing and directing an affair, knowing something with the senses, certified something and acknowledging it (Mu'jam al-Wasit, 2004). Al-Taarruf's metaphor is related to the sense of smell that is used by qiyas in knowing someone, it also shows a tendency for a person to be calm about something. Al-Taarruf is related to the sense of smell that is used by qiyas in knowing someone, it also implies a tendency and calmness towards something. (Ibn Faris, 1999:282).

Based on the explanatory aspects of the language under discussion it shows that the word alTa'arruf which is derived from the base word 'arafa as well as other words evolved from its base word and it has a broad meaning. Furthermore, it can be seen that there are few meanings related to Ta'aaruf itself such as knowing and interacting, managing the various affairs, being responsible, recognizing, acknowledging, inclination and inner peace in interacting, doing good and charity. This gives the impression that Ta'arruf's words cover all the aspects mentioned. Hence, Allah Almighty uses this Ta'arruf word as He says in verse 15 of surah al-Hujurat. It explains the concept of universal human relations without limitation, regardless of skin color and culture, it also involves aspects of managing differences, sharing knowledge, doing good and benevolence with one another, recognizing the rights of every nation, recognizing the contribution of each race and so on.

\section{The Explanation of Al-Ta'arruf According to the Quran And The Sunnah}

In verse 13 of surah al-Hujurat Allah SWT says:

Meaning: O mankind! We have indeed created you from one man and one woman, and have made you into various nations and tribes so that you may know one another; indeed the more honourable among you, in the sight of Allah, is one who is more pious among you; indeed Allah is All Knowing, All Aware.

The nation in that verse is interpreted by scholars such as the Mujahid, the Qatadah and alDahhak as the distant lineage or the al-Nasab al-Ba'id while the Kabilah is interpreted as a close line or al-Nasab al-Qarib (al-Tabariy, 2001). An example given by exegesis members is that al-Mudhar is an Arab nation while Tamim is a tribe that is part of al-Mudhar (al-Tabariy 2001). In this verse Allah explains the purpose of being multiracial, clans and tribes is for the purpose of getting to know one another, at the same time the most virtuous of them is to protect himself by fulfilling all religious duties and avoiding evil and sin. The glory is not measured by material and lineage (al-Tabariy, 2001). 
From the Islamic perspective, humans are descended from the prophet Adam and his wife Eve. This is like the explanation of Allah Almighty in surah al-Nisa 'verse 1:

Meaning: $O$ men! Fear your Lord Who created you from a single being and out of it created its mate; and out of the two spread many men and women.1 Fear Allah in Whose name you plead for rights, and heed the ties of kinship. Surely, Allah is ever watchful over you.

The above verse is to make people aware that they are the descendant of Adam and his wife Eve. Thus, it is a requirement for all people to build good relationships with one another regardless of race and skin color. This good relationship is included in the concept of alTa'arruf as found in the surah al-Hujurat verse 13 above.

This is what has been emphasized by Ibn-Asyur (1984) that Allah SWT invokes in that verse with the cry of men and not in the cry of believers is the purpose of making people realize that the origin of man is one of the offspring of Adam and Eve, thus, their glory does not lie to their lineage but rather lies to the righteous.

The call with the cry of men shows that al-Ta'arruf revolves around the nations and also the country. Certainly the taaruf is not only limited from the aspect of recognizing names and places of residence merely and its even wider than that. It includes the aspects of recognizing culture, sharing knowledge and intelligence, getting benefits from the technology, learning languages, working together in various fields. All of these aspects contribute to social and national stability, leading to the unity of the races hence establishing peace and harmony environment.

Therefore, to ensure that this al-Ta'arruf is maintained and strengthened, all people in the society must be involved. Every individual regardless of race, skin color and position needs to appreciate and practice al-Ta'arruf's principles such as sincerity and justice. The ethics such as cooperation and tolerance should also be used. While challenges that can hinder alTa'arruf's success such as prejudice and ethnocentrism for example must be overcomed with variety of strategies through the country's management and administration systems, including legal aspects. This means that in order to ensure that the concept of Li Taarafu or al-Ta'arruf is able to achieve its objectives, a comprehensive effort that is known as up down and bottom up should be practiced together.

If the verses in surah al-Hujurat are refined, especially those that came before the 13th verse, then there are descriptions outlining some important concepts that can be related to alTa'arruf. In verse 9, the principle of sincerity, the duty of having peace in dispute is emphasized in this verse. Allah said:

Meaning: And if two factions among the believers should fight, then make settlement between the two. But if one of them oppresses the other, then fight against the one that oppresses until it returns to the ordinance of Allah. And if it returns, then make settlement between them in justice and act justly. Indeed, Allah loves those who act justly.

The above verse is a 'means of enlightenment' to protect society from any strife, in the event of a dispute between the two parties, it is necessary for the third party to reconcile and make settlement between them. If the other party refuses and continues to do wrong, then the other party must be opposed until they return to make peace and obey the command of Allah the Almighty. All parties have to abide by to the truth and the dispute should be settled by the principles of justice (Qutb, 2003).

In the racial relations, whether they belong to the same race or among the different races there is often dispute happened. This is due to various reasons such as political, religious or racial differences. This situation needs to be settled in accordance with laws and regulations fairly as a step towards maintaining the peace and harmony of the community. If in the case 
of an armed war Allah has ordered that peace to be restored, then it should as well be practised in a situation involving the verbal conflict. Thus returning to peace is a symbol of an appreciation of sincere principles and practicing good manners. Is/ah or the effort to bring peace is also a strategy to restore the harmony in society. Therefore, any dispute must be resolved on the basis of truth and justice.

There are also factors that can cause conflict and dispute that will disrupt the integrity of the relationship among the races. These factors are explained by Allah SW T in the next verse. Allah said in verse 11.

Meaning: $O$ you who have believed, let not a people ridicule [another] people; perhaps they may be better than them; nor let women ridicule [other] women; perhaps they may be better than them. And do not insult one another and do not call each other by [offensive] nicknames. Wretched is the name of disobedience after [one's] faith. And whoever does not repent - then it is those who are the wrongdoers.

There are various exegesis' opinions on why this verse is quoted. Among them was Ibn Abbas, a verse that forbids mocking each other in connection with the rebuke of a friend named Thabit Ibn Qais Ibn Syammas that called the individual sitting next to the Messenger of Allah with a bad name during the time of ignorance (jahiliyyah), then the individual bowed his face in shame for the title. (al-Baghawiy, 2010).

According to al-Dahhak, this verse was revealed in connection with the Bani Tamim who came to Medina, they looked down on some of the Companions Allah's Messenger (may peace be upon him) that are poor such as Ammar, Khabbab, Bilal, Suhaib, Salman and Salim Mawla Abu Huzaifah, then the verse was sent down. (al-Baghawiy, 2010). While Anas narrated, this verse came down as a warning to the wives of the Messenger of Allah (may peace be upon him) who called Ummu Salamah a short person, while from the history of the Ibn 'Abbas in the Qur'an, this verse is a reference to a woman in the time of the Prophet who called Sofiyyah Binti Huyay with the name Yahudiyyah Binti Yahudiyyin (al-Bagahwiy, 2010).

In this case, the act of making fun of or mocking and demeaning others in any form and word that is understood to be the purpose of any of those is prohibited by religion (al-Tabariy, 2001). His assertion is reinforced by the words of the Messenger of Allah from the history of Abdullah Ibn Mas'ud RA:

Meaning: Takkabur means rejecting the truth and looking down on people." (Muslim, 2000, no. 91, Kitab al-Iman).

Based on this hadith that it is illegal to look down and mock on someone (Ibn-Kathir, 2002). Furthermore, the act of denouncing someone is also strictly prohibited. Similarly, the practice of summoning and giving bad names to a particular race or individual is also forbidden as it is the practice of the Jahiliyyah (Ibn-Kathir, 2002).

There is no doubt that all the speeches, expressions, titles and words of insult, underestimate or looking down on someone as forbids by the religion will be the cause for the fight. Thus religion prohibits it because it will only brings harm.

In that surah, there is also the prohibition of bad manners, backciting and spying on someone in specific to purposely find their fault. This is what Allah Almighty says in verse 12:

Meaning: O you who have believed, avoid much [negative] assumption. Indeed, some assumption is sin. And do not spy or backbite each other. Would one of you like to eat the flesh of his brother when dead? Youwould detest it. And fear Allah; indeed, Allah is Accepting of repentance and Merciful.The prejudice in the verse refers to the nature of prejudice that is defamatory. It is to acuse a person with sin and evil, while he has no evident on that. The evidence that shows te word prejudice here means accusation is the next verse explaining the 
prohibition of seekin out and recognizing others' mistakes (al-Qurtubiy, 2006). The act of deliberately seeking out thers' mistakes is due to bad intentions and has the purpose to tarnish the individual's image. his affirmation is explained in the words of the Prophet Muhammad (peace be upon him) rom the hadith narrated by Abu Hurayrah RA:

Meaning: "Beware of suspicion, for suspicion is the greatest falsehood. Do not try to find fault with each other, donot spy on one another, do not vie with one another, do not envy one another, do not be agry with one another, do not turn away from one another, and be servants of Allah, broters to one another, as you have been enjoined. " (Al-Bukhariy, 2000).

The nature of presuppoition here is probably closer to the meaning of prejudice, which is an unreasonable feeling oropinion on something that involves race, religion an so on. (Kamus Dewan 2015). The exisence of these qualities within an individual or a race can be a barrier to the harmony in each ther, whether it be between individuals or between races. In addition to prohibited traits or prctices is to backbite or say something about whatever flaws a person has. This is exactly wha the Prophet (peace and blessings of Allah be upon him) explained in the hadith narrated Ab Hurayrah RA, when he asked about the meaning of al-Ghibah or backbiting, he replied :Meaning: "Saying something abut your brother that he dislikes." It was said, "What if what I say about my brother is true?"He said, "If what you say is true then you have backbitten about him, and if it is not true, thn you have slandered him." (Muslim, 2000, no. 2489, Kitab al-Bir wa al-Silah wa al-Adaab).According to al-Nawawiy, what a persn hates involves his body, his religion, his life, his behavior, his circumstances, his propert, his parents, his children, his wife, his aides, his clothes and so on (Ibn Hajar, 1986). Inthis regard, all of the above-mentioned attitudes and practices are undoubtedly damaging tosociety, including relationship among the races. In the context of relationship among the races any form of words and practices that are contemptible and despicable are strictly foridden by religion and are contrary to the human nature which do not like to be insulted or degraded.

Qutb (1994); Ibn-Asyur (1984)in discussing the above verses explains that after Allah SWT mentioned in regard to the above-mentioned practices and attitudes such as bloodshed, fight, dispute, words of contempt, downgrading people, prejudice, and so forth, then in the 13th verse Allah swt calls out to the cry of man. The call is to fully informed that man and woman are created by Him. The existence of different races and colors of skin is also from His creation. So the purpose of human creation in such a way is not to be argued, hate, despise or kill each other, but the purpose of human creation in different ways is to have taaruf and be at peace with one another.

Ibn Umar RA recounted that at the opening of the city of Mecca or Fath Mecca, the Messenger of Allah (may peace be upon him) preached:

Meaning: People of Quraysh, surely God has abolished from you all pride of the time of ignorance and all pride in your ancestry, because all men are descended from Adam, and Adam was made of clay". Allah said: "O mankind, indeed We have created you from male and female and made you peoples and tribes that you may know one another. Indeed, the most noble of you in the sight of Allah is the most righteous of you. Indeed, Allah is Knowing and Acquainted. (Al-Tirmidhiy, 1996).

The above hadith clearly shows that pride and grandeur of the tribe is a practice of ignorance that is forbidden by Islam. In other words, ethnocentrism is the idea that their ethnic or tribe is better and superior than others and this is something that is prohibited by Islamic teachings. This practice of ignorance in ancient times where some of the Arab tribes feel that they are more noble than others, so they insult and look down upon other things as they do on kabilah Bahilah, Dubay'ah and Bani 'Ukl (Ibn-Asyur, 1984). Ethnocentrism is also not a value of one's 
glory. But instead it is the contribution of good deeds that is counted. Therefore, ethnocentrism is forbidden by Islam, as it will cause fight, dispute and even murder. This will threaten the stability of the country and the unity of the people.

This statement is further supported by the hadith narrated by Ahmad (1993) in his musnad, Abi Nadrah explained that he heard from what was said to him that the Messenger of Allah (may peace be upon him) during his preaching on the day of Tasyriq said:

Meaning: O people, verily your Lord is One and your father is one. Verily there is no superiority of an Arab over a non-Arab or of a non-Arab over an Arab, or of a red man over a black man, or of a black man over a red man, except in terms of taqwa (Ahmad, 1993).

Thus in the al-Taarruf contexts, the differences in the creation of human beings are not intended to fight with to one another, to hate or to create conflict, but such differences are seen as positive opportunities for mutual benefit from cultural, knowledge, science, skills and so on. Every nation in the world has its own strengths and advantages. For instance, the strength possesed by the Japanese is probably not exist for the Europeon or Asian and vice versa. Therefore, all that is needed is to interact and communicate with each other for the benefit, knowledge and skills. The glory of a nation depends on how much they benefit others in all aspects of life. Thus, in the reality of intenational relations, there are many developed countries that are well respected because of their strength and contribution to the progress and prosperity of the world. For example, Japan is one of the most respected countries in the world. The Japanese people are generally not only known for their positive culture and ethics, but their scientific and technological advances and high skills are recognized in the eyes of the world.

\section{The Wisdom of Diversity of Races and Tribes}

The diversity of races and tribes as well as the differences in skin color and appearance are within the scope of the will and determination of Allah the almighty that is All Knowing. No one know exactly what is the wisdom and purpose of human creation in such condition. However, it is compulsory for us to believe that every single things happen for a reason. Allah SWT makes these differences a sign of His greatness. Allah SWT said in surah al-Rum, verse 22:

Meaning: And of His signs is the creation of the heavens and the earth and the diversity of your languages and your colors. Indeed in that are signs for those of knowledge.

According to Ibn-Asyur (1984) This verse is preceded by a sign of the power and wisdom of Allah the Almighty by mentioning the creation of the heavens and the earth, and then by mentioning the differences of language and skin color of the human body. This is because the heavens and the earth have a very important role in shaping the language, skin color, appearance and behavior of the human. The geographical position of a country in terms of geography, weather and season certainly influences the formation of these differences.

Although humans are of the same kind of beings, verbal differences indicate the differences in language spoken by humans. While the differences in spoken language show a sign of Allah's greatness in human beings, it also affects the way we think and act. This, has an impact on the way humans respond to their surroundings to sustain their lives. In other words, these differences influence and shape one's own way of life, living systems and values. The differences in skin color also affect the appearance of the human while the weather and the seasons as found in certain countries such as winter, spring, fall and summer affect the formation of their skin color and looks. 
There are exegesis who have the discretionary judgement to define the original color of the human. According to Ibn-Asyur (1984), Ibn Sina in his work al-Tib argues that the original color of the human body is black and white, through surgery it is proven that there is only one color in the flesh beneath the skin. From the white and black it splits and forms a variety of skin colors such as yellow, brown and red. In his view the origin of the human color can be divided into 3 main parts, the white belongs to the Caucasian race, the yellowness of the Mongolian descent and the blackness of the Habhasian lineage.

It should be noted here that Islam recognizes the diversity of races and tribes with the different of skin color. It is therefore not in the teachings of Islam that teach its believer to hate or to look down upon any race or ethnic group. However, Islam strictly opposes racism. This is because such traits have a negative effect on the relationship among the races. This matter has been emphasized:

Meaning" He is not one us who calls for Assabiyyah (clanism/ Nationalism/Tribalism/racism) or who fights for Assabiyyah or who dies for Assabiyyah (Abu Dawud 2009)"

The meaning of the Assabiyyah aspect of the hadith is to invite the unity in the name of a people, or state or in other words, it is to obsolutely support of any race or country even it is against the truth. (Aabadiy, 2005; Al-Qari', 2001)

In the context of the relationship among the race in Malaysia, if referred to the racial or ethnic of the origin such as the Malay, Chinese, Indian and indigenous people of Sabah and Sarawak, it can be viewed that there are various of different ethnics and languages. The indian tribes that originally comes from India have at least six main ethnics namely Negrito, Proto, Mongoloids, Dravidian, Brachycephals and Aryan. Each ethnic group is divided into other subethnicities (Ahmad, 2017,40). There are various languages spoken, but only 22 languages are recognized by the constitution as official languages such as Assamese, Bengali, Dogri, Gujarati, Hindi, Kashmiri, Konkani, Maithili, Marathi, Nepali, Oriya, Punjabi, Sanskrit, Sindhi, Urdu, Kannada, Malayalam, Tamil, Telugu, Bodo, Manipuri dan Santhali (Britannica, 2019).

Whereas the Chinese ethnicity, there are about 56 ethnicities recognized by the Chinese Government. Among them are Han, Zhuang,Hui, Manchu, Uighur, Miao, Yi, Tujia, Tibetan, Mongol, Dong, Buyei, Yao, Bai, Korean, Hani, Li, Kazakh, and Dai (CIA World Factbook, Jan.20 2018). The main language spoken are Uyghur, Cantonese, Mongolian, Hakka, Hmong, Shanghai, Korean, Tibetan, Kazakh.

While Malay ethnics are the indigenous people divided into 3 main groups namely Negrito, Proto and Senoi. Senio group is divided into Temiar, Jahut, Semai, Che Wong, Semoq Beri and Mah Meri. Proto Malays are divided into Temuan, Semelai, Jakun, Orang Laut or Kuala, Seletar and Kanaq. The Negrito Group is divided into Kesui, Jahai, Kintaq, Mendriq, Bateq, Lanoh (www.jakoa.gov.my, 2019).

Generally in Malaysia, there are about 70 ethnic groups with different languages and dialects. If it is considered a sub-ethnicity then it can reach over 200 ethnic groups (Amri 2012, 13).

In this regard, Malaysia is a democratic country with a multi-ethnic, religious, languages and cultural community that shows a wide range of level in managing and governing the country. This diversity has made Malaysia as a unique country and people can live together in peace and harmony under one government. This method of unity is the result of a national governance concept based on the racial integration (Zaliza \& Norlin, 2009: 143).

It can be understood that the existence of various races and tribes has its own wisdom and benefits. But based on reality, each race has its own strengths that can be combined for the 
purpose of enriching human life. Each race plays a role in complementing each other where each race plays a role and contributes to the development of the community and the nation holistically.

\section{Relationship between Takwa and Al-Ta'arruf}

Generally, takwa refers to fulfilling the commands of Allah Almighty and avoiding His prohibitions (Ibn-Rajab 2008). One of the religious mandates is to foster the relatioship with one another and to cooperate with each other in a positive and beneficial way. In relation to this, Allah Almighty states in surah al-Nisa 'verse 1:

Meaning: "O mankind, fear your Lord, who created you from one soul and created from it its mate and dispersed from both of them many men and women. And fear Allah, through whom you ask one another, and the wombs. Indeed Allah is ever, over you, an Observer." In the above verse Allah SWT begins with the divine command to have fear upon Him with the purpose of making man aware that $\mathrm{He}$ is the Creator of Adam and Eve and thus mankind is developing offspring among men and women of his generation. The second commandment to fear Allah in this verse is to remind the people that they are calls to upholding of the ties of kinship and forbid them from break it off as described by Ibn Abbas, Mujahid and Ikrimah and others (Ibn-Kathir, 207, 2002). This verse also clearly illustrates the unity of society, all of which originate from a single soul or nafs (Qutb: 575, 1994).

This clearly illustrates that one of the demands of the takwa is to foster closer the relationship with one another. In other words, the aspect of sillaturahim is within the meaning of alTa'arruf itself. What is important to be understood is that this relationship is not limited to fellow Muslims only, but it does involves the relationship with the people of different religions and beliefs. However, Islam still imposes restrictions that need to be maintained in order for it to be on the path that is allowed by the religion.

The Messenger of Allah (may peace be upon him) said from a hadith narrated by Abdullah Ibn Umar RA:

Meaning: A Muslim is a brother of another Muslim, so he should not oppress him, nor should he hand him over to an oppressor.

The same rules applies to the relationship with non-Muslims. In relationship with the parents for example, Allah SWT commands that they must be kind to both as described in surah AlAnkabut verse 8:

Meaning: "And We have enjoined upon man goodness to parents. But if they endeavor to make you associate with Me that of which you have no knowledge, do not obey them. To Me is your return, and I will inform you about what you used to do."

Allah the Almighty also says in verse 15 of surah al-Ahqaf.

Meaning: "And We have enjoined upon man, to his parents, good treatment."

These verse 8 of surah al-Ankabut and verse 15 of surah al-Ahqaf are revealed in connection with the events of Saad Ibn Abi Waqqas who converted to Islam and he was a devoted son to his mother. His mother refused to eat food and drink and stay without shelter and was willing to die before Saad returned to his previous religion. Saad then said:

Meaning: "Ya Ummah! (O mother) In spite of my strong love for you, my love for Allah and His Messenger is indeed stronger. By Allah, if you had a thousand souls and one soul after another were to depart, I would not abandon my religion for anything."

Hence, after giving up on Saad finally his mother started to eat and drink. Then, the verse 8 of surah al-Ankabut came down explaining the demands to be kind to parents including the non-Muslims. (al-Baghawiy, 2010). It can be understood in this context that a child has to 
maintain a good relationship with his or her parents despite of their difference in religion. This is considred as the matter of takwa.

In the same issue, there was once the Mother of Asma' Binti Abi Bakr RH which her name is Qutaylah Binti Abdil Uzza who is not a muslim came to visit Asma, , she was not sure whether she was allowed to receive gifts from her non-Muslim mother or not. She went to the Prophet (PBUH) to ask him t regarding to that matter:

Meaning : My mother came to me, hoping (for my favor) during the lifetime of the Prophet asked the Prophet, "May I treat her kindly?" He replied, "Yes."

Hence, Sufyan Ibn 'Uyyaynah whis was one of the narrators of this hadith said, then Allah Almighty revealed verse 8 of surah al-Mumtahanah:

Meaning: Allah does not forbid you from those who do not fight you because of religion and do not expel you from your homes - from being righteous toward them and acting justly toward them. Indeed, Allah loves those who act justly (Al-Bukhariy, 2000; Kiritsis, 2014).

The same rules should be implied with the relationship among the relatives of different religion. Islam also allows a muslim to make a will for their relatives although they are not Islam. As explained by Allah Almighty in verse 6 of surah al-Ahzab:

Meaning: "The Prophet is more worthy of the believers than themselves, and his wives are [in the position of] their mothers. And those of [blood] relationship are more entitled [to inheritance] in the decree of Allah than the [other] believers and the emigrants, except that you may do to your close associates a kindness [through bequest]. That was in the Book inscribed.

The above explanation shows that al-Taaruf through sillaturrahim relationships is a practice of takwa.With the existence of al-Taaruf based on takwa to Allah Almighty, this will strengthen and build a sincere and honest relationship without any negative feelings such as bad thinking. This will make it easy to create good relationships and contribute to one another. This is in line with the word of Allah Almighty in surah al-Maidah verse 2:

Meaning: "And cooperate in righteousness and piety, but do not cooperate in sin and aggression."

In this context, interaction and cooperation are good and beneficial according to the religion. It is not considered as cooperation for the matters that is forbids by the religion. Rasulullah SAW once allowed the Khaibar Jews to plant on Muslim and the cultivated corps were shared according to mutual agreement as stated by Abdullah Ibn Umar RA (Al-Bukhariy, 2000).

Therefore, co-operation is closely related to one's expertise and ability regardless of ones race and ethnicity. In Malaysia, this aspect is very clear, where in various sectors of development cooperation and interaction occurs not only for the people in the same tribes but also happen among the different races.

\section{Conclusion}

Al-Ta'arruf is a concept of the relationship among the races that is so broad and deep in understanding. The concept is not limited to only know the ones personal name. In fact, its is about the concept of the knowledge of the culture and the way of living of a community. AlTa'arruf also is a concept to manage all the difference in the best manner. The strength of a nation is not measured on the basis of skin color but rather on the determinants of success and the strength of the nation lies in the positive attitude and their contribution. 


\section{References}

Al-Tabariy, I. J. (2001) Jaam'i al-Bayan an Ta'wil Aay al-Quran. Kaherah: Dar Hijr.

Aabadiy, S. A. (2005). 'Aun al-Ma'bud 'ala Syarh Sunan Abi Dawud. Beirut: Dar Ibn Hazmn.

'Umar, A. M. (2008). Mu'jam al-Lughah al-'Arabiyah al-Mu'asirah. Kaherah: 'Aalam al-Kutub. Ahmad, I. H. (1993). Musnad al-Imam Ahmad. Beirut: Dar Ihya al-Turath al-'Arabiy.

al-Qari', A. I. S. M. (2001). Mirqaat al-Al-Mafaatiih. Beirut: Dar al-Kutub al-'Ilmiyyah;

Al-Albaniy, N. (2000). Sahih Sunan al-Tirmidhiy. Riyad : Maktabah al-Maarif.

Al-Albaniy, N. (2004). Silsilah al-Ahadith al-Sahihah. Riyad: Maktabah al-Maarif Li al-Nasyr.

Al-Baghawiy, I. M. (2010). Maalim al-Tanzil. Beirut: Dar al-Kutub al-Ilmiyyah.

Al-Bukhariy, I. (2000), Sahih al-Bukhari. Riyad.

Ibn-Faris, A. A. (1999). Mu'jam Maqayis al-Lughah. Beirut: Dar al-Jail.

Ibn-Manzur, M. I. (1993). Lisan al-'Arab. Beirut: Dar Saadir.

Ibn-Asyur. (1984). Tafsir al-Tahrir wa al-Tanwir. Tunisia: Dar al-Tunisiyyah Li al-Nasyr.

Ibn-Kathir, O. (2002). Tafsir al-Quran al-Azim. Riyad: Dar al-Tayyibah.

Ibn-Hajar. (1986). Fath al-Baariy. Kaherah: Dar al-Rayyan li al-Turath.

Mas'ud, J. (1992). Al-Raa'id Mu'jamun Lughawiyun 'Asriyyun. Beirut: Dar al-'Ilm Li al-Malayiin. Al-Qurtbiy, I. A. (2006). Al-Jaami' li Ahkam al-Quran. Beirut: Muassasah al-Risalah.

Baharuddin, S. A. (2012). Modul Hubungan Etnik. UKM:Institut Kajian Etnik.

Qutb, S. (1994). Fi Zilal al-Quran. Beirut: Dar al-Syuruq .

Kiritsis, D. (2014). Educational Aims and Professional Fulfillment. Multilingual Academic Journal of Education and Social Sciences, 2(1), 26-35.

Al-Tirmidhiy, I. I. (1996). Al-Jami' al-Kabir (Sunan al-Tirmidhi). Beirut: Dar al-Gharb al-Islamiy. Zaliza \& Norlin. (2009). Pembangunan Sosial Dalam Hubungan Etnik. Dalam Kassim Thukiman, Rahman, H. A. (2009). Hubungan etnik di Malaysia: Perspektif, Teori dan Praktik. UTM. 